\title{
Crop Concentration and Crop Diversification in Birbhum District of West Bengal: Recent Situations
}

\author{
Prabuddha Ray
}

10.18805/ag.R-2120

\begin{abstract}
Background: Crop concentration focuses on the pre-dominance of certain crops over other crops in a specific area under study. On the other hand, Crop diversification refers to the various types of crops grown in a specific time period under the study area. If the numbers of different types of crops grown in an area during a specified time period is more, the area will have the higher crop diversification and vice versa. So, Crop Concentration and Crop Diversification reveal changing pattern of competition among various crops for getting prominence over other crops.

Methods: The present study was initiated to have an analysis of present situation regarding the crop concentration and crop diversification in Birbhum district of West Bengal over the years of 2012-13, 2013-14, 2014-15, 2015-16 and 2016-17 through interpretation of the data related with the area, production and productivity data of the major crops of the district obtained from the Govt. of India data source. (aps.dac.gov.in/APY/Public-_Report1.apx). In this study, the crop concentration of Birbhum district is delineated with the help of the Crop Concentration Index of Bhatia (1965) and crop diversification is assessed with the help of the Gibbs and Martin Index of diversification (1962).

Result: The present study clearly finds out that the crop concentration index of Birbhum district is low as the mean of the Indices is 34.01 with corresponding standard deviation (SD) of 0.2997 and co-efficient of variance (CV) of Indices is as low as 0.0088 over a period of five years from 2012-13 to 2016-17. This study also reveals that in Birbhum district only 2 crops having more than 10 per centage point share in the gross cropped area (GCA) of the district provides the farmers a wide scope of farming various different crops or group of crops. The present study also points out that the district has a fairly diversified pallet of crops as the Mean value of crop diversification indices is 00.64754 with a standard deviation of as negligible as 00.0001 with a minute CV of Indices of 00.00016 for the time period of 5 years i.e. from 2012-13 to 2016-17, having potential for further well planned diversification of the crops.
\end{abstract}

Key words: Crop concentration, Crop diversification, Crop concentration index, Crop diversification index.

\section{INTRODUCTION}

Birbhum district is one of pre-dominantly agriculture based district as far as the economic activities are concerned. It is pertinent to mention that 23.95 per cent (amounting to $8,38,764$ numbers of persons) of the total population of $35,02,404$ of the district are directly engaged in agricultural as their main occupation either in the capacity of cultivators or agricultural labourers as per 2011 census of Govt, of India. According to the Department of Agriculture, Govt. of West Bengal, 79.17 per cent of the agricultural land in Birbhum is under ownership of marginal farmers who own $0.1-1.0$ hectare of land and 15.41 per cent of the district agricultural land under the possession of the small farmers who own 1.1 - 2.0 hectares of land; thus making these two categories of farmers owning an over whelming 94.58 per cent of the agricultural land of the district. Here lies the importance of exploring the scenario concerning the crop concentration and crop diversification of the District; as these two aspects have immense potential to influence the economic output and efficiency of the agricultural land in question. If a concerted effort to be put in place for increasing the real income of the farmers and as well as the economic efficiency of the farms, it is imperative to know what is the present
Department of Agricultural Extension, Rathindra Krishi Vigyan Kendra, Palli Siksha Bhavana (Institute of Agriculture), VisvaBharati, Sriniketan-731 236, West Bengal, India.

Corresponding Author: Prabuddha Ray, Department of Agricultural Extension, Rathindra Krishi Vigyan Kendra, Palli Siksha Bhavana (Institute of Agriculture), Visva-Bharati, Sriniketan-731 236, West Bengal, India. Email: prabuddha_ray1@rediffmail.com

How to cite this article: Ray, P. (2021). Crop Concentration and Crop Diversification in Birbhum District of West Bengal: Recent Situations. Agricultural Reviews. DOI: 10.18805/ag.R-2120.

Submitted: 13-10-2020 Accepted: 04-10-2021 Online: 03-11-2021

status of the district on the above mentioned two aspects viz. crop concentration and crop diversification.

Crop concentration focuses on the pre-dominance of certain crops over other crops in a specific area under study. Concentration of crops depends on bio-physical factors like physiography, topography and fertility of soil, quality and availability of seeds; situational factors like climate, irrigational facilities and socio-economic factors like land ownership pattern, extent of farm credit flow, supply chain mechanism for farm inputs, marketing aspects, consumer preferences etc.; e.g. the areas of low rainfall and absence 
of irrigation facilities may have the dominance of millet crops like Bajra, Jowar, Ragi, pulses etc. and whereas high rainfall areas may see production of cash crops like Jute which prefers standing water for its vegetative growth.

On the other hand, crop diversification refers to the various types of crops grown in a specific time period under the study area. If the numbers of different types of crops grown in an area during a specified time period is more, the area will have the higher crop diversification. Diversification also reveals changing pattern of competition among various crops for getting prominence over other crops.

Agricultural diversification is an important agroeconomic strategic tool for economic growth through reducing the exposure of risks associated with farming through product diversification, enhancing the efficiency of the farm lands, as especially small and marginal farm holdings as our case is and to increase the income of the farmers through production of high crops having market potential.

In the context of India, in the post-Independence period, the area under food grains especially high yielding dwarf varieties of wheat and later high yielding dwarf rice crops increased substantially partly due to their yield potentials being achievable in the North Indian Gangetic Peninsula and South Indian Cauvery - Godavari Delta regions through the expansion of irrigational facilities and assorted green revolution technology packages and partly due to governmental policies of encouraging bumper food production and eliminating food imports. As a result, in the later decades there was overwhelming tendency towards cereal centered specialization, causing huge gap in demand and supply of oilseeds and pulses in India.

The changing trend in total areas under crops is natural as in a dynamic world, certain modification can occur in the existing pattern of land utilization (Lekhi and Singh, 2011). As Deka et al. (2018) noted that it was becoming a necessity to examine the land use scenario and cropping pattern of a specified area based on the concept of crop diversification. Thus a minute study of crop concentration and crop diversification provides the stakeholders a strategy to optimize the use of land, water and other resources of an area by cultivating more profitable crops. It provides the farmers a pallet of choices to decide from what to cultivate on their land which will generate maximum returns. Generally Indian farmers follows the same cropping pattern decades after decades neglecting the aspects of advantages of Crop diversification which may provide them capability to avoid risk and un-certainty due to climatic and biological vagaries, especially in the emerging climate change situation.

So, the economic utility of the study of the crop concentration and crop diversification lies in the implied shift from less profitable and non sustainable crops to more profitable and sustainable crops. In the Indian farming arena after liberalization, privatization and globalization (LPG) being initiated in the Nineties of the last century, the focus is now being shifted to have natural resource efficiency and sustainability, ecological balance and employment generation potential of the small and marginal farms with overall emphasis on increasing the real income of the farmers.

When the numbers of different types of crops decline over a specified area and time of reference, then it can be indicated to a trend towards the dominance of mono-culture practices. In this type of situation, crop concentration is more in that particular frame of references. On the other hand, crop diversification helps to know the contemporary competition amongst the crops for an area and scope for rotation and effects on double cropping or multiple cropping, total production and per hectare productivity (Hangaragi, 2010). crop diversification in other words refers to a farming system in which multiplicity of crop characterizes the agricultural landscape of a specific unit of area over a specified time period. The nature of crop diversification differs among the farming situations due to existence of a wide heterogeneity in agro-climatic conditions. The socioeconomic and technological factors also play an important role in changing crop diversification (Todkari et al., 2010).

In this paper, the present author will try to analyze the crop concentration and crop diversification aspects of the district of birbhum to find out whether there is any space and to what potential extent further allocation of more areas to especially pulse and oilseeds production is possible in the district giving rise to a more efficient crop diversification scenario.

\section{MATERIALS AND METHODS}

The present study was initiated to assess the recent trend in the crop concentration and crop diversification in Birbhum District of West Bengal over the years of 2012-13, 2013-14, 2014-15, 2015-16 and 2016-17.

\section{The objectives of the present Study are}

1. To delineate the crop concentration scenario of the district of Birbhum.

2. To assess the status of crop diversification in the afore said district and

3. To suggest some ameliorative strategies for making future acreage and production targets concerning the field crops robust and sustainable.

To achieve the above mentioned objectives, the author has used the area, production and productivity data of the major crops of the Birhum district obtained from the crop Production Statistics Information System, Special Data Dissemination Standard Division, Directorate of Economics and Statistics, Ministry of Agriculture and Farmers' Welfare, Govt. of India (Internet Source:-aps.dac.gov.in/APY/ Public-_Report1.apx). Thus data regarding the changes in Agriculture situation with reference to Area, Production and Productivity of crops of Birbhum District in last Five Years viz. from the financial year of 2013-14 to the financial year of 2017-18 (as per availability of Data) was collected as secondary database and analyzed. 
In the present study, the crop concentration of Birbhum district is delineated with the help of the crop concentration Index of Bhatia (1965) and crop diversification is assessed with the help of the Gibbs and Martin Index of diversification (1962).

For the measurement of crop concentration Bhatia in 1965 developed a formula based on Gross Cropped Area (GCA). The formula has been expressed as:

Index of crop concentration =

Percentage of sown area under $X$ Crops Number of $X$ Crops

Where

"X" crops are those crops that individually occupy 10 per cent or more of the GCA of the area under study. The main advantage of this index of crop concentration is that it provides an indirect approach to assess the degree of crop diversification in the area under study and its relationship with the dominant crops of the area. If a large numbers of crops each having about 10 per cent or more of the GCA, the higher is the crop diversification of the area under study. Thereby, a high crop concentration Index value shows lesser diversification and increased specialization and a low crop concentration Index value shows higher diversification.

To find out the extent of crop diversification achieved in the area under study, the secondary data is analysed with the help of the Gibbs-Martin Index of Diversification (1962) that provides a useful Index for measuring the degree of diversification in the cropping pattern in a specific area and the formula developed for the calculation of the Crop Diversification Index is as under:

$$
\text { Index of crop diversification }(I C D)=1-\frac{\sum X^{2}}{\left(\sum X\right)^{2}}
$$

Where

" $X$ " is the percentage of total cropped area occupied by each crop or hectarage under individual crop.

For calculating crop concentration index only the crops occupying 10 per cent or more of the gross cropped area of Birbhum district viz. Kharif rice and Boro rice were considered for statistical analysis, whereas for calculating crop diversification index all the crops or groups of crops grown in Birbhum district viz. 26 numbers of crops or groups of crops i.e. (1) Aus rice (Autumn rice); (2) Kharif rice; (3) Boro rice; (4) Wheat; (5) Maize; (6) Rapeseed and mustard; (7) Sesamum; (8) Linseed; (9) Other oilseeds (excluding rapeseed and mustard, sesamum and linseed); (10) Gram / Bengal gram / Chick pea; (11) All Kharifpulses; (12) All Rabi pulses (except gram / Bengal gram / Chick pea); (13) Chillies; (14) Ginger; (15) Turmeric; (16) Betel nut; (17) Other spices and condiments (excluding chillies, ginger, turmeric and betel nut); (18) All fruits; (19) Potato; (20) All vegetables (except potato); (21) Other minor food crops; (22) Coconut; (23) Sugarcane; (24) Jute; (25) Sunn hemp; (26) Drugs, marcotics and plantation crops and (27) Fodder crops) were taken into account.

\section{RESULTS AND DISCUSSION}

The secondary data related to the percentage of area under each crop in relation to the gross cropped area of the Birbhum district has been calculated from the data source mentioned above. Thus, the calculated percentage under each crop (mentioned as X) are presented below.

The statistical analysis of the data (obtained from Table 1) was further analyzed to have a focus regarding crop concentration and crop diversification in Birbhum district and the resultant analysis are being represented as under.

From Table 2, it can be noted down that from the year 2012-13 to the year of 2016-17, the crop concentration index of Birbhum district remained more or less varied as the coefficient of variance (CV) of the indices is as low as 0.0088 . As the $C V$ is simply a measure of dispersion of the variables, the Bhatia's index of crop concentration of Birbhum district over years as mentioned is less dispersed. This refers to the fact that the distribution of Indices of crop concentration in Birbhum district of West Bengal in the mentioned time series is around the mean. Hence, dispersion of crop concentration indices is very low. The small standard deviation (SD) of 0.2997 also confirms that the values of the data set concerning the crop concentration index are close to the mean of the data set. This small SD points that the crop concentration index of Birbhum district has not

\section{Gibbs-Martin Index of Crop Diversification}

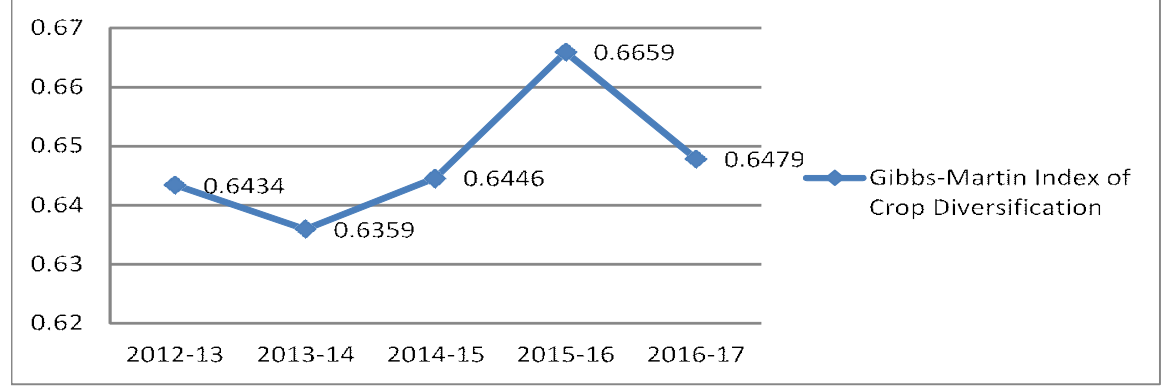

Fig 1: Trends of crop concentration in Birbhum district over the years. 


\section{Bhatia's Index of Crop Concentration}

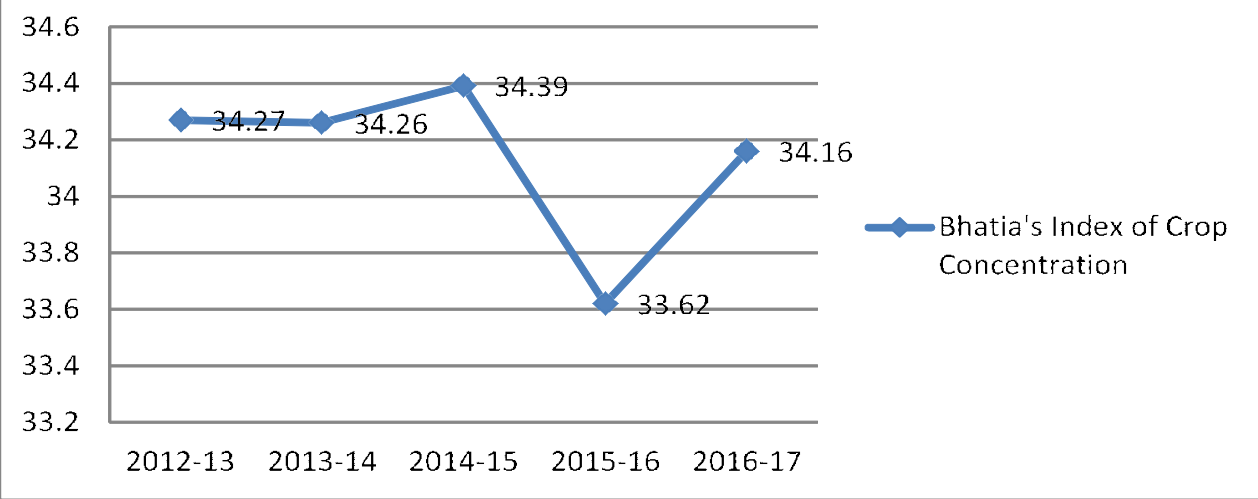

Fig 2: Trends in crop diversification in Birbhum district over the years.

Table 1: Percentage of area under each crop in relation to the gross cropped area of the Birbhum district $(\mathrm{X})$.

\begin{tabular}{|c|c|c|c|c|c|}
\hline Crop & $\begin{array}{c}\text { Year } 2012- \\
13\left(X_{1}\right)\end{array}$ & $\begin{array}{c}\text { Year } 2013- \\
14\left(\mathrm{X}_{2}\right)\end{array}$ & $\begin{array}{c}\text { Year } 2014- \\
15\left(\mathrm{X}_{3}\right)\end{array}$ & $\begin{array}{c}\text { Year } 2015- \\
16\left(X_{4}\right)\end{array}$ & $\begin{array}{l}\text { Year } 2016- \\
17\left(X_{5}\right)\end{array}$ \\
\hline Aus rice (Autumn rice) & 0.46 & 0.5 & 0.47 & 0.41 & 1.08 \\
\hline Kharif rice & 57.95 & 57.82 & 56.79 & 54.86 & 56.75 \\
\hline Boro rice & 10.59 & 10.69 & 11.98 & 12.37 & 11.57 \\
\hline Wheat & 6 & 6.2 & 6.03 & 5.72 & 5.07 \\
\hline Maize & 0.04 & 0.02 & 0.08 & 0.08 & 0.09 \\
\hline Rapeseed and mustard & 5.81 & 6.01 & 6.2 & 6.07 & 5.75 \\
\hline Sesamum & 0.94 & 0.91 & 0.9 & 0.89 & 1.02 \\
\hline Linseed & 0.03 & 0.04 & 0.05 & 0.13 & 0.03 \\
\hline $\begin{array}{l}\text { Other oilseeds (Except rapeseed and } \\
\text { mustard, sesamum and linseed) }\end{array}$ & 0.03 & 0.03 & 0.03 & 0.03 & 0.09 \\
\hline Gram / Bengal gram / Chick pea & 1.32 & 1.28 & 1.22 & 1.71 & 1.33 \\
\hline Other Pulses (Kharif) & 0.08 & 0.03 & 0.05 & 0.06 & 0.1 \\
\hline Other Pulses (Rabi) (Except gram) & 1.69 & 1.67 & 1.65 & 3.88 & 3.26 \\
\hline Chillies & 0.11 & 0.11 & 0.11 & 0.1 & 0.11 \\
\hline Ginger & 0.15 & 0.14 & 0.14 & 0.13 & 0.14 \\
\hline Turmeric & 0.07 & 0.07 & 0.07 & 0.07 & 0.07 \\
\hline Betelnut & 0.01 & 0.01 & 0.01 & 0.01 & 0.01 \\
\hline Other spices and condiments (Excluding & 0.04 & 0.04 & 0.04 & 0.04 & 0.04 \\
\hline \multicolumn{6}{|l|}{ Chillies, ginger, turmeric and betel nut) } \\
\hline All Fruits & 1.05 & 1.04 & 1.1 & 1.07 & 1.11 \\
\hline Potato & 3.31 & 3.27 & 2.91 & 2.86 & 2.68 \\
\hline Seasonal vegetables except potato & 9.83 & 9.57 & 9.71 & 9.16 & 9.29 \\
\hline Other minor food crops & 0.03 & 0.03 & 0.03 & 0.03 & 0 \\
\hline Coconut & 0.07 & 0.07 & 0.07 & 0.07 & 0.07 \\
\hline Sugarcane & 0.16 & 0.14 & 0.13 & 0.13 & 0.19 \\
\hline Jute & 0.06 & 0.16 & 0.06 & 0.03 & 0.03 \\
\hline Sunn Hemp & 0.02 & 0.02 & 0.02 & 0.02 & 0.02 \\
\hline Drugs, narcotics and plantation crops & 0.01 & 0.01 & 0.01 & 0.01 & 0.01 \\
\hline Fodder crops & 0.12 & 0.12 & 0.12 & 0.11 & 0.11 \\
\hline
\end{tabular}

Secondary data source: - Crop production statistics information system, special data dissemination standard division, Directorate of economics and statistics, Ministry of agriculture and farmers' Welfare, Govt. of India (Internet Source: aps.dac.gov.in/APY/Public-_Report1.apx). 
Table 2: Crop concentration in Birbhum district over the years.

\begin{tabular}{lc}
\hline Year & Bhatia's index of crop concentration \\
\hline $2012-13$ & 34.27 \\
$2013-14$ & 34.26 \\
$2014-15$ & 34.39 \\
$2015-16$ & 33.62 \\
$2016-17$ & 34.16 \\
Mean & 34.14 \\
SD & 0.2997 \\
CV of Index & 0.0088 \\
\hline
\end{tabular}

Table 3: Crop diversification in Birbhum district over the years.

\begin{tabular}{lc}
\hline Year & Gibbs-Martin index of crop diversification \\
\hline $2012-13$ & 0.6434 \\
$2013-14$ & 0.6359 \\
$2014-15$ & 0.6446 \\
$2015-16$ & 0.6659 \\
$2016-17$ & 0.6479 \\
Mean & 0.64754 \\
SD & 0.0001 \\
CV of Index & 0.00016 \\
\hline
\end{tabular}

changed dramatically over the years and it hovers around the mean of the data set i.e. 34.01 which is itself a low figure. The Table 2 and Fig 1 also reveal that in Birbhum district, the crop concentration index is continuously low from 201213 to 2016-17 and there is ample scope for crop diversification.

From Table 3, it can be noted down that from the year 2012-13 to the year of 2016-17, the crop diversification index of Birbhum district remained less varied as the co-efficient of variance (CV) of the Indices is as negligibly low as 0.0001 . As the $\mathrm{CV}$ is simply a measure of dispersion of the variables, the Gibbs-Martin Index of crop diversification of Birbhum district over years as mentioned is less dispersed. This refers to the fact that the distribution of Indices of crop diversification in Birbhum district of West Bengal in the mentioned time series is around the mean value of the data series i.e. 00.64754. Hence, dispersion of crop concentration indices is very low. The small and negligible standard deviation (SD) of 0.00016 also confirms that the values of the data set concerning the crop diversification index are close to the mean of the data set. This small SD points that the crop diversification index of Birbhum district has not changed dramatically over the years and it hovers around the mean of the data set which is itself a high figure of 00.64754. The Table 3 and Fig 2 also reveal that in Birbhum district, the crop diversification index is continuously high from 2012-13 to 2016-17 and the farming community of the district in question utilizes the opportunity arising out of low crop concentration indices amply presented in Table 2 and also in Fig 1.

\section{CONCLUSION}

The present study clearly finds out that the crop concentration index of Birbhum district is low as the mean of the indices is 34.01 with corresponding standard deviation (SD) of 0.2997 and co-efficient of variance (CV) of indices is as low as 0.0088 over a period of five years from 2012-13 to 2016-17 (see Table 2 and Fig 1). This indicates the Birbhum District has fairly low level of crop concentration continuously in the last five years as mentioned implying only 2 crops having more than 10 per centage point share in the gross cropped area (GCA) of the district providing the farmers a wide scope of farming various different crops or group of crops.

The present study also reveals that the district has a fairly diversified pallet of crops as interpreted from Table 3 and Fig 2 showing the Mean value of crop diversification indices is as high as 00.64754 with a standard deviation of as negligible as 00.0001 with a minute CV of Indices of 00.00016 for the time period of 5 years i.e. from 2012-13 to 2016-17. This means that the huge majority of gross cropped area of Birbhum district are under multi-cultural condition with mono-culture is being limited as demand of increased production and productivity compel the farming community of the district to go for production of a diverse set of crops over the same piece land in last five or more years. This trend for crop diversification is fairly consistent for the specified time period as mentioned above.

A thorough scrutiny of the Table 1 of the present study there is enough scope for expansion of the areas under oilseeds, pulses, fruits and drugs, narcotics and plantation crops in Birbhum district as these crops has potential in the district but its area is very low. The dry and semi-arid red lateritic zones of the district are highly favourable for production of seeds. These groups crops and also seed production of cereals, pulses, oilseeds and vegetables should be the focus of future thrust activities.

\section{REFERENCES}

Bhatia, S.S. (1965). Pattern of crop concentration and diversification in india. Economic Geography. 41(1): 39-56.

Deka, N., Hazarika, J.P., Bora, P.P. and Buragohain, R. (2018). Change in land use and cropping pattern in Assam: An Economic Analysis. Economic Affairs. 63(1): 39-43.

Gibbs, J. and Martin, W. (1962). Index of Diversification. In: Quantitative Techniques in Geography: An Introduction. [R. Hammond and P.S. McGullagh (eds.)] Clarendon Press, Oxford, p. 21.

Hangaragi, S.S. (2010). Measurement of agricultural efficiency and planning for sustainable development in drought prone area: A case study of Bagalkot district of Karnataka. Trans. Inst, Indian Geographers. 32(2): 127-136.

Lekhi, R.K. and Sigh, J. (2011). Agricultural Economics an Indian Perspective. New Delhi: Kalyani Publishers.

Todkari, G.U., Suryawanshi, S.P., Suryawanshi, M.V. and Patil, B.D. (2010). Agriculture Landuse Pattern in Solapur District of Maharashtra. International Journal of Agriculture Sciences. 2(2): 01-08. 